\title{
Mathematical analysis of capillary elevation in porous limestone
}

PÉTER JUHÁSZ - Department of Construction Materials and Engineering Geology, Faculty of Civil Eng. BME - juhasz.p@eik.bme.hu

SzILVIA BÉLA - Department of Geometry, Institute of Mathematics, BME - belus@math.bme.hu

KATALIN KOPECSKÓ - Department of Construction Materials and Engineering Geology,

Faculty of Civil Eng. BME - katalin@eik.bme.hu

Received: 09. 06. 2013. - Érkezett: 2013. 06. 09. - http://dx.doi.org/10.14382/epitoanyag-jsbcm.2013.1

\section{Abstract}

Absorption and transport of water in porous stone materials is an important issue, since it is often related to the durability and deterioration of the material. Traditional standardized tests are aimed to determine the rate of absorption or water-permeability by measuring the weight or volume of absorbed water through a given surface area with time. Nevertheless, in situations like wetting of stone or brick walls not only the quantity of the absorption is important, but also the maximum height and velocity of the water-front elevation should be considered. In present paper the relationship between the velocity of capillary elevation and height of capillary elevation is studied. The aim of the analysis was to find an equation which characterizes the measured absorption process adequately. Three types of power functions were used to approximate the velocity of the water-front elevation. These approximating functions were computed for 13 measurements made with porous limestone, and the accuracy of the approximations was evaluated. It was found, that equations in the form of $v_{(h)}=c / h+d$ can be fitted to the measured data with high accuracy, and the possible range of the $c$ coefficient was determined for porous limestone.

Keywords: capillary elevation, approximating function, velocity of capillary elevation, porous limestone

\section{Introduction}

Rate and intensity of capillary suction are important characteristics of porous stone materials, since momentary and local rate of saturation, as well as water-content are depending on these characteristics. Moreover, both the rate of saturation and the water-content has an effect on strength, load-bearing capacity and durability of the porous material [1]. Therefore, characteristics such as water permeability are often measured and evaluated in the geological and engineering practice [2].

In air-dry condition the most important factors which determine the rate of water-absorption are the apparent porosity and the pore structure, i.e. the pore size-distribution of the material. There are three main directions of water transport according to the orientation of the movement related to the influence of the gravity force: horizontal, vertical downward and vertical upward directions. In case of the horizontal water transport (such as horizontal underground sand layers surrounded by watertight clay layers) the effect of gravity can be ruled out. In case of the vertical downward water transport, absorption is enhanced by the gravity; on the other hand vertical upward water transport is hindered by the gravity force.

Vertical upward water transport is usually referred to as capillary elevation or capillary suction. The most important effects of capillary elevation on the construction materials and structures are related to the water and the solved components introduced into the stone by the water. Porous materials that became saturated or partly saturated with water by the capillary elevation will be exposed to deterioration due to freezing-thawing. When crystal-forming chemicals (salts) are introduced into the material, pressure by the forming of crystals might also deteriorate the material when it dries out.

Péter JUHÁSZ

1985) architect (MSc, 2010). Graduated in

2010, at the Department of Construction Technology and Management, of the Budapest University of Technology and Economics. Started his research work in 2007 in the field of heritage conservation management. In 2006 and 2009 he received traineeship at the National Office of Cultural Heritage. Since 2010, he has been PhD student at the Budapest University of Technology and Economics, Department of Construction Materials and Engineering Geology. His field of research is biomineralization of porous stone materials.

Szilvia BÉLA (1983) mathematician (PhD, 2011). Completed her MSc studies in mathematics in the field of geometry at the Faculty of Natural Sciences of Budapest University of Technology and Economics in 2007. Completed her Phd studies at the Department of Applied Geometry, Johannes Kepler University, Linz, Austria. She has been assistant professor at the Department of Geometry, Institute of Mathematics, Budapest University of Technology and Economics since 2012. Her field of research is applied and computational geometry, modelling, CAGD.

Katalin KOPECSKó (1961) chemical engineer (PhD, 2000) associate professor at the Budapest University of Technology and Economics, Department of Construction Materials and Engineering Geology. Graduated in chemical engineering (1990) and has postgraduate studies in concrete technology (2004). Her fields of research are: deterioration processes of construction materials, durability of concrete and other materials, hydration of cement, diagnostics of historical buildings and ornamental stones, mineralogical properties of stones and soils, studies of physical and chemical changes by XRD and TG/DTG/DTA.

Moreover, wetting of the foundation of a building due to the water absorbed from the soil often leads to the deterioration and loss of strength. Furthermore, continuous wetting of construction materials initiates biocolonisation by fungi.

Nevertheless, the theoretical background of the mathematical modelling of flow in porous media is well founded [3], according to the literature there are hardly any measurements on the evaluation of the capillary elevation process. In our research we evaluated the capillary elevation characteristics. The velocity of elevation and its dependence on the momentary height of elevation was evaluated by using data obtained from a capillary elevation test that was performed on porous limestone specimens.

The aim of this study was to set up an equation based on empirical data, which describes well the capillary elevation process up to the equilibrium condition. Furthermore, after finding the general form of the best fitting equation for the measured values, we determined the range of coefficients that are typical for porous limestone. Accuracy of the fitting was determined, as well.

\section{Materials and methods}

\subsection{Stone material and preparation of the samples}

Porous limestone was used in present experiments. The origin of the limestone is the Sóskút quarry in Hungary. Sóskút 
limestone has an oolitic-bioclastic fabric, which is highly porous, up to $40 \mathrm{v} / \mathrm{v} \%$. Altogether 13 cylindrical specimens were drilled out of blocks, with radius of $36.84 \pm 0.07 \% \mathrm{~mm}$ and height of $89.8 \pm 0.78 \% \mathrm{~mm}$. Apparent density, real density and total porosity of the specimens were measured according to the MSZ EN 1936:2007 standard 'Natural stone test methods. Determination of real density and apparent density and of total and open porosity'. Apparent porosity was calculated by dividing the volume of the absorbed water with the volume of the specimen at the atmospheric water saturated condition. Measurements were carried out under $24.5^{\circ} \mathrm{C}$.

\subsection{Capillary elevation test}

Capillary elevation test was performed in vertical position by hanging the specimens on a hook of an Archimedes-balance (see Fig. 1). Two rulers with millimeter scale were mounted on the two sides of the specimens, along their length. This was necessary since the water-front of the absorption seldom raises parallel to the plane of the water surface. However, in case of a cylinder, average elevation height is the mean value of the two elevation heights measured on the two sides of the specimen. Capillary suction was initiated by pouring water into a bowl under the hanged specimen until it reached the bottom of the cylinder. Continuous water supply was either ensured by the layer of water attached to the bottom of the specimen due to surface tension linking the surface of water to the specimen. Moreover, sinking of the specimen hanged on the balance followed the decreasing water level. Surfaces of the cylinders were not protected against evaporation, since the gap between the wrapping material and the surface of the specimen could have acted as a macro pore, influencing the measurement.

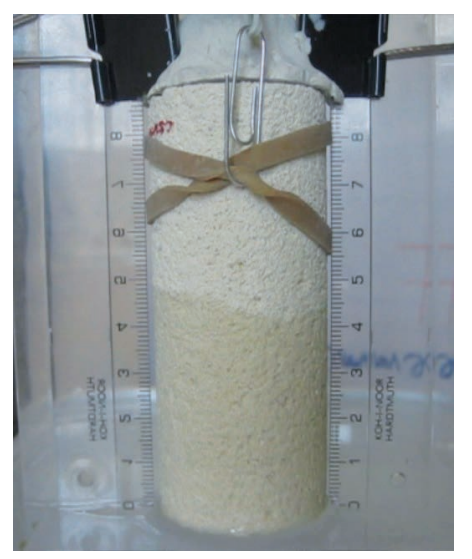

Fig. 1. Testing setup for the capillary elevation measurement

1. ábra Kapilláris vízfelszivás vizsgálati elrendezése

The process was recorded to video by means of a digital camera (in $640 \times 480$ pixels resolution) until the water-front reached the top of the specimen. Momentary elevation heights were determined by the video recordings, and momentary velocities of capillary suction were calculated and evaluated in function of the elevation height. During the tests the measured values were the elevation height ( $h$ in $\mathrm{mm}$ ) of the water-front in the limestone and the velocity of the water-front ( $v$ in $\mathrm{mm} / \mathrm{s})$. The measurements were taken about 30-40 times in different heights along the length of each limestone sample.
Elevation heights in time were read from the videos with an accuracy of $0.5 \mathrm{~mm}$. Instants of the readings were dependent on the clear visibility of the edges of the water-front on the cylinder in the video.

According to the evaluation of previous measurements it was realized that the process of the capillary elevation in a complex pore-system can be described with a function.

\subsection{Mathematical analysis of the measured data}

In order to analyze the data ( $v$ and $h$ ) obtained from the measurements, a guiding principle was the equation of the fluid front velocity in a capillary pore with given radius [4]:

$\mathrm{v}(\mathrm{h})=\frac{\mathrm{r}^{2}}{8 \eta \mathrm{h}}\left(\frac{2 \delta \cdot \cos \theta}{\mathrm{r}}-\mathrm{g} \rho \mathrm{h}\right)$

Here the radius of the capillary pore is denoted by $r$. The values of $\eta, \delta$ and $\theta$ depend on the temperature of the fluid. The acceleration of gravity is given by $g$ and the density of the fluid is $\rho$. Eq. (1) is derived from the Navier-Strokes equation, by considering vertical upward direction of the flow [5]. The equation also shows that the velocity and the height of the liquid front are in inverse proportionality, namely

$$
\text { where } \quad \mathrm{c}=\frac{\mathrm{r} \cdot \delta \cdot \cos \theta}{4 \eta}, \quad \begin{aligned}
& v(h)=\frac{c}{h}+d, \\
& \text { and } \quad d=-\frac{r^{2} g \rho}{8 \eta} \text {. }
\end{aligned}
$$

The measured data of the 13 different limestone samples were analyzed first with the help of commercial spreadsheet software. We have approximated each data set using a power function estimate, which is given in the general form of

$v(h)=\frac{c}{h^{\alpha}}$.

The approximating functions were generated with different $c$ coefficients in the range of 15 to 48 . The exponent a was chosen in the range of 0.979 to 1.186 . From the values of the exponent it is realized that the approximated velocity function behaves similarly as in Eq. (1) - in the case of capillary pore with given radius. Therefore, the further velocity approximating functions were computed with a similar form like that of Eq. (1). We generated two different approximation functions for the measured velocity of each limestone sample with using the program package of Wolfram Mathematica 8.

The first approximating function was given in the form of

$v(h)=\frac{c}{h}$,

where the value of the coefficient $c$ was computed with the least squares method. The values were in the range of 16 to 25 , they had a smaller deviation than the coefficients computed by the previous approximations.

According to the velocity equation for capillary pore with given radius Eq. (1), a second approximating velocity function was computed for each measurement. This function was searched in the form of

$v(h)=\frac{c}{h}+d$,

where the value of the coefficients $c$, $d$ were assigned by the least squares method. 
After setting up the equations in the form of Eqs. (3) and (4), coefficients $c$ and $d$ were compared with those calculated from Eq. (1) in order to see if any equation belonging to one discrete pore-size can describe the elevation process. Moreover, coefficient $c$ obtained from Eqs. (2), (3) and (4), as well as the accuracy of the approximation were also compared with each other in order to determine the best fitting form of equation.

\section{Results and discussion}

\subsection{Mass properties of the limestone specimens}

Dry masses of the specimens were measured, and by dividing them with the volumes, mass densities were calculated to be $1.56 \pm 0.45 \% \mathrm{~g} / \mathrm{cm}^{3}$. Real density of the limestone was measured to be $2.69 \pm 0.89 \% \mathrm{~g} / \mathrm{cm}^{3}$, and the total porosity was calculated to be $0.42 \pm 0.62 \%$. Apparent porosity of the specimens was calculated to be $0.325 \pm 1.90 \%$ corresponding to the atmospheric water saturated condition.

\subsection{Capillary elevation test}

The specimens showed similar behaviour during the capillary elevation tests. The curves fitted to the measured points by commercial spreadsheet software were found to be very similar. Differences in the slopes of the curves can be contributed to the fact that porous limestone is not homogenous in its structure. This leads to local acceleration or slowdown in the capillary elevation along the specimen.

\subsection{Mathematical analysis of the measured data}

The values of coefficient $c$ for the three different approximating functions corresponding to each measurement data are compared in Fig. 2. It can be seen, that coefficient $c$ was found in a wide range (13 to 47 ), when they were calculated by the in-built module of the commercial spreadsheet software in form of Eq. (2). The smallest deviation of the coefficient $c$ was obtained by the approximating function of Eq. (3). However, the deviation of the coefficient $c$ was larger in the case of Eq. (4) (between 15 and 31), the approximation of the measured data was improved compared to the results provided by Eq. (3).

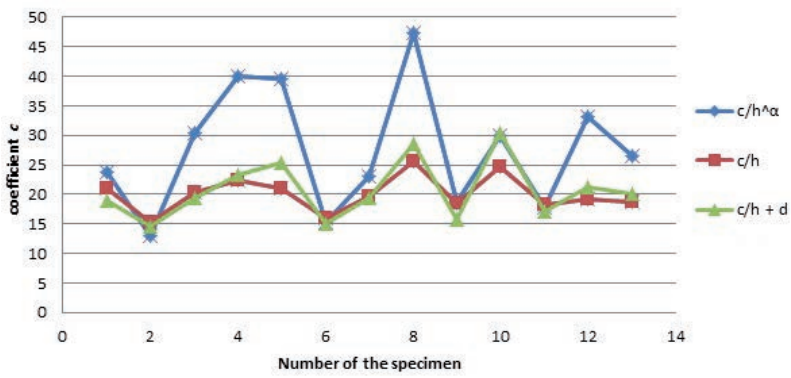

Fig. 2. Comparison of coefficient $c$ in the approximated velocity functions 2. ábra A c együttható összehasonlitása a sebesség becslö függvényekben

In case of the approximation given by Eq. (4), the constant $d$ was chosen from a small range starting from -0.08 up to 0.06 computed by the least squares algorithm. These values are partly in line with Eq. (1), where the coefficient $d$ is below zero. Physical explanation of this effect is that above a certain height the pores cannot retain the water, thus it starts to sink.
Consequently, the sign of the velocity of the capillary elevation turns to be negative. This occurs above a certain height, where the ratio $-c / h$ is equal to coefficient $d$. Therefore, in practice coefficient $d$ is expected to be negative, otherwise the velocity of the capillary elevation would not turn to be zero.

In Fig. 3. the approximation of the measured values are shown for sample No.13. The functions are generated either by Eq. (3), or by Eq. (4).

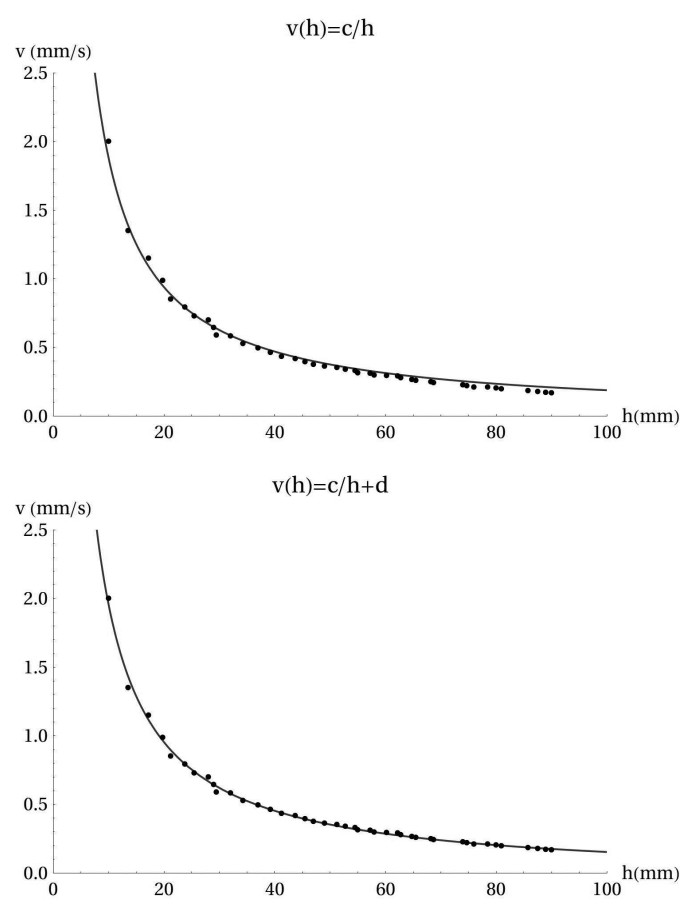

Fig.3. Approximated velocity functions for limestone sample No.13. a) By Eq. (3) the function is $v=18.7674 / \mathrm{h}$ and the coefficient of correlation is 0.99128

b) By Eq. (4) the function is $v=19.9934 / \mathrm{h}-0.047$ and the coefficient of correlation is 0.9968

3. ábra A 13. sz mészkö minta becsült sebesség függvényei

a) A (3) képlet szerint $v=18.7674 / h$ és a korrelációs együttható 0.99128

b) A (4) képlet szerint v=19.9934/h-0.047 és a korrelációs együttható 0.9968

\begin{tabular}{llll} 
No. of specimen & $\begin{array}{c}\text { Eq. (2) } \\
\mathbf{R}^{\mathbf{2}}\end{array}$ & $\begin{array}{c}\text { Eq. (3) } \\
\mathbf{R}^{\mathbf{2}}\end{array}$ & $\begin{array}{c}\text { Eq.(4) } \\
\mathbf{R}^{\mathbf{2}}\end{array}$ \\
$\mathbf{1}$ & 0.9834 & 0.95812 & 0.97351 \\
\hline $\mathbf{2}$ & 0.9875 & 0.97357 & 0.97775 \\
\hline $\mathbf{3}$ & 0.9767 & 0.96532 & 0.96780 \\
\hline $\mathbf{4}$ & 0.9881 & 0.98056 & 0.98308 \\
\hline $\mathbf{5}$ & 0.9963 & 0.94031 & 0.97820 \\
\hline $\mathbf{6}$ & 0.9954 & 0.98171 & 0.98917 \\
\hline $\mathbf{8}$ & 0.9914 & 0.98781 & 0.98789 \\
\hline $\mathbf{9}$ & 0.9946 & 0.98217 & 0.99758 \\
\hline $\mathbf{1 0}$ & 0.9858 & 0.90627 & 0.95067 \\
\hline $\mathbf{1 1}$ & 0.9921 & 0.94311 & 0.99016 \\
\hline $\mathbf{1 3}$ & 0.9884 & 0.96101 & 0.96961 \\
\hline
\end{tabular}

Table 1. Coefficients of correlation $\left(R^{2}\right)$ by fitting the approximating functions given in Eqs. (2) to (4).

1. táblázat A (2)-(4) képletek szerint becsült függvények korrelációs együtthatói $\left(R^{2}\right)$ 
Coefficients of correlation $\left(\mathrm{R}^{2}\right)$ of the fitting by the three different formulae are given in Table 1. It can be seen, that the approximation by the function covering coefficient $d$ enhances the correlation of the fitted function.

From the measurements and calculations it was realized, that capillary elevation in complex pore-systems cannot be described with an equivalent pore-size diameter belonging to one discrete pore-size, as it could be described by Eq. (1). The coefficients $c$ and $d$ in Eq. (4) are chosen from a different range than for velocity functions by Eq. (1) for equivalent pore size. However, the general form of the function is the same in Eqs. (1), (3) and (4).

\section{Conclusions}

It was found, that equations in the form of $v_{(h)}=c / h+d$ can be fitted on the measured $(v ; h)$ points with high accuracy. For this form of equation, the possible range of the $c$ coefficient was calculated to be between 14.5 and 30.43 for the porous limestone of Sóskút. Coefficient $d$ was found in the range of -0.08 to 0.06 . If the level of the source of water (where $h=0$ ) can be measured or estimated, then the velocity of the capillary elevation can be calculated for different heights in practice with the help of the proposed equation and the coefficient $c$. For the calculation of the maximum height of capillary elevation at the equilibrium point a coefficient $d$ smaller than zero should be chosen. The model can be used for structural elements endangered by salt attack or freezing-thawing.

It can be realized from the measurements and calculations that capillary elevation in complex pore-systems cannot be described with an equivalent pore-size diameter belonging to one discrete pore-size. Approximation of the pore-size distribution based on the data obtained from the capillary suction test is aim of our future research. Further aim is the empirical determination of the velocity of capillary suction into the horizontal and vertical downward directions in porous stone materials.

\section{Acknowledgement}

The work reported in the paper has been developed in the framework of the project „Talent care and cultivation in the scientific workshops of BME" project. This project is supported by the grant TÁMOP-4.2.2.B-10/1--2010-0009.

\section{References}

[1] Török, Á. -Vásárhelyi, B.: The influence of fabric and water content on selected rock mechanical parameters of travertine, examples from Hungary. Engineering Geology, 2010, No. 115, pp. 237-245

[2] Savoye, S. - Michelot, J.-L. - Matray, J.-M. - Wittebroodt, C. - Mifsud, A.: A laboratory experiment for determining both the hydraulic and diffusive properties and the initial pore-water composition of an argillaceous rock sample: A test with the Opalinus clay (Mont Terri, Switzerland). Journal of Contaminant Hydrology, 2012, No. 128, pp. 47-57

[3] Szymkiewicz, A.: Modeling Water Flow in Unsaturated Porous Media Accounting for Nonlinear Permeability and Material Heterogenity. Springer, 2013, 237 p.

[4] Kriston, L.: Basic knowledge on the restoration of plasters and stone materials (in Hungarian: A kő és vakolat restaurálás alapismeretei). Notes for the students of the Hungarian University of Fine Arts, Hungarian University of Fine Arts, 2000, 125 p.

[5] Bear, J.: Dynamics of fluids in porous media. Dover Publications Incorporated, 1988, $764 \mathrm{p}$.

\section{Ref.:}

Péter Juhász - Szilvia Béla - Katalin Kopecskó: Mathematical analysis of capillary elevation in porous limestone.

Építőanyag, 65. évf. 1. szám (2013), 2-5. p.

http://dx.doi.org/10.14382/epitoanyag-jsbcm.2013.1

\section{A kapilláris vízfelszívás matematikai modellezése} durva mészkő esetén

A porózus kôanyagok vízfelszivása és a bennük zajló transzportfolyamatok gyakran összefüggésbe hozhatóak az anyag tartósságával és tönkremenetelével. A hagyományos, szabványos vizsgálatok célja a vízfelvétel intenzitásának és a vízáteresztési képességnek a meghatározása. Ezek során az adott idố alatt felvett vagy átáramlott víz tömegét mérik. Gyakorlati szempontból azonban nemcsak a nedvességtartalom vagy a felvett víz tömegének ismerete fontos, hanem a vízfelvétel magassága és a vízfelvétel sebessége is. Jelen cikk a vízfelvétel magasságának és sebességének összefüggését vizsgálja. A vizsgálat célja egy olyan függvény meghatározása, amely kellô pontossággal leírja a kapilláris vízfelvétel sebességét. A magasságtól függố kapilláris-emelkedési sebesség értékek függvénnyel történố közelítésére három különbözô típusú hatványfüggvény vizsgálata történik meg. A közelítések során 13 darab hengeres mészkô próbatesten mért értékek alapján történik a függvények illesztési pontosságának elemzése. A cikk rámutat, hogy legjobban a $\mathrm{v}_{(\mathrm{h})}=\mathrm{c} / \mathrm{h}+\mathrm{d}$ alakban megadott függvények írják le a kapilláris vízfelvétel sebességét, és ezekhez meghatározható a c együtthatók lehetséges értéktartománya is durva mészkố esetére. Megállapítható, hogy a durva mészkô anyaghoz tartozó $v_{\text {ch }}$ függvény nem feleltethetố meg egyetlen, konkrétan adott pórusmérethez tartozó $v_{(h)}$ függvénynek sem. Ebbôl az következik, hogy a komplex pórushálózat vízfelvételi sajátságai eltérnek az egy adott pórusra jellemzô vízfelvételi sajátságoktól.

Kulcsszavak: kapilláris felszívás, becslố függvény, vízfelszívás sebessége, durva mészkô

\section{International Conferences}

- SB13 Graz - International Conference on Sustainable Buildings "Construction Products and Technologies"

2013 September $25-28$

Organiser: TU Graz and ITTB

http://www.sb13.org/index.php/en/

- $3^{\text {rd }}$ International RILEM Workshop on Concrete Spalling due to Fire Exposure

2013 September 25-27

Organiser: CSTB, TU Delft and MFPA

http://www.firespalling2013.fr/
- RILEM-fib-AFGC International Symposium on Ultra-High Performance Fibre-Reinforced Concrete (UHPFRC)

2013 October 1-3

Organiser: AFGC, RILEM and fib

http://www.afgc.asso.fr/index.php/uhpfrc2013

- SB13 Guimarães - Sustainable Building Contribution to Achieve the EU 20-20-20 Targets

2013 October 30-November 1

Organiser: University Minho and University Lisbon

http://www.iisbeportugal.org/portugalsb13/pt/index.html 